\title{
LIFE, HACKED
}

\author{
Outfor a duck.
}

\section{BY KRYSTAL CLAXTON}

$\mathrm{T}$ he man is and is not a god.

The prayer is not whispered in temple. It is arranged in subatomic particles.

"I want out," I say through teeth gritted against the stale air of my tiny lab.

$\mathrm{He}$ is amused. His teeth are preternaturally white. "That's an unusual request. Most people want more of 'in' if you will to live forever."

I don't remember the walk to the bus stop. The ride back to my apartment. The passage of time.

Possibly this is because I don't really walk and there isn't really a bus and I don't really have an apartment. Maybe driving is the mechanism for loading this new environment. The teleportation spell, the computation that gets me from there to here, a loading screen.

Or possibly because I'm in shock.

The man is and is not a genie.

The summons is not sent by rubbing a lamp. It is agitated by a subterranean high-powered laser.

"I want to be real." My entire life, existence, indeed the existence of everything, culminates in this.

His smile is proud, a glint in his sky-blue eyes. I have not only discovered the false nature of life, but want actualization. He could be a happy father if he didn't look so like a child about to squash a bug.

I look around the faded coral walls of my cheap rental, the only thing I can afford within commuting distance to my lab. It's not the sort of place you'd use a spell to get to, if you could do magic.

I'm going to vomit, which is a high irony indeed, and when I get to the sink, I swallow and breathe and cry. And scowl at my face in the mirror. A face designed and coded without my input - whether by DNA or $\mathrm{C}++$. Maybe nothing has changed.

Something brushes against my thumb.

The man is and is not a dragon.

DNATURE.COM Follow Futures: @ @NatureFutures f go.nature.com/mtoodm
The deal is not sealed in blood. It is expressed at a frequency that should not exist.
"Tell me how you figured it out," he commands.

"And you'll make me..." I'm not sure what I'm asking for and can't look him in the eye. The lab's ancient CRT monitor flashes black, then displays a geometric screensaver.

"I will provide you with a synthetic body in the real world."

I nod. Humanoid or not, that's more real than this.

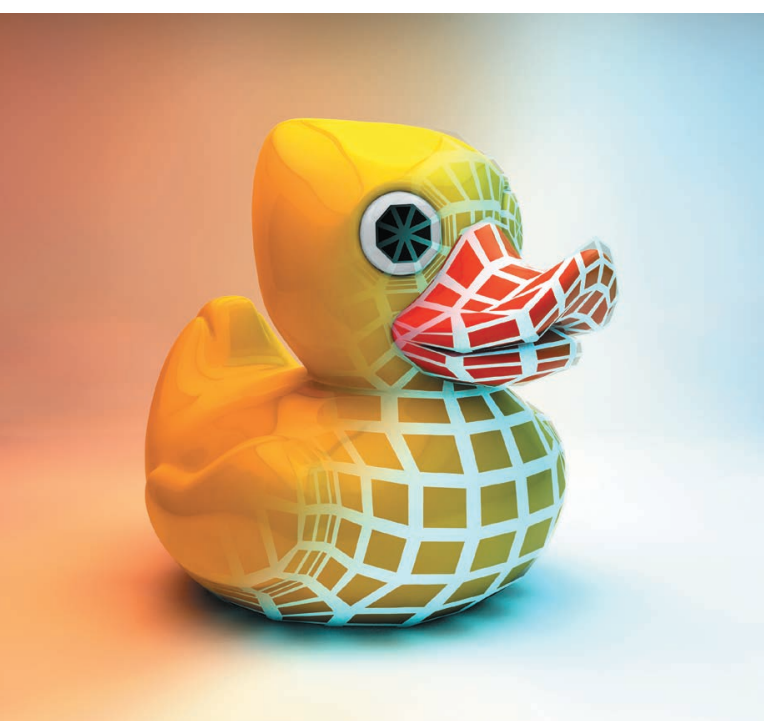

I look down and there's a rubber ducky sitting on the bathroom sink that I've never seen before. Or I have, but I've never seen it in person. It's that one from the Sesame Street song about Ernie, bath time and fun. But it wasn't here before.

I pick it up and feel - know - it's not a duck.

The man is and is not in the world. His face is too perfectly symmetrical. He breathes hot air into the cramped space. He's unbearably beautiful. He has no scent.

"Deal," I say and offer him my hand, which he accepts.

How do you know that the devil will keep his word? How do you hold a thing like this accountable for its promises? A thing that can erase your mind. A thing that can delete you.

I explain my research. The impossible maths that reflected a world unlike our own. My suspicion that it was a gateway, a leak, a vibration from another plane in the multiverse. And how the probability of this world being a simulation was greater than any of those other options.
He narrows his eyes as he listens and I wonder if, for him, the world comes equipped with AR or a HUD. If he's repairing the infinitesimal flaw I found even now. If he's using cheat codes. If I were him, I would be. I finish speaking.

I wait. He watches. Nothing happens. "You said -"

"How do you know that I haven't already granted your request?"

I'm dumbfounded, gesture to everything, to my continued existence, such as it is.

Now he laughs and I am certain he is a petty god, a capricious genie, a cruel dragon. "That's not how data work. Software is copied to hardware, not transported. It's not moving tangerines from Florida to Cincinnati."

I glare. He's absolutely right. He might be lying or he might have copied me to an android body in some unreachable perfect world where subatomic particles always obey consistent laws. How would I know?

Is the clone living in a synth body out there somewhere the real one now?

How I envy her. What does that make 'me'? Leftovers? A registry stub?

"Well. You've been very helpful." He winks at me and vanishes from existence with the same flourish that he appeared. With a flash of light and a brimstone scent. With a snap-pop and a breeze as the air in my lab rushes to fill the void left by the matter that no longer exists.

I unclench my hands and see that I've carved up my palms with my fingernails. There will never be a way out. Not for me. No matter how many copies make good on the goal of finding benevolent masters and real synthetic bodies, there will always be something left behind.

It's not a duck. It's a gift. From a version of me that is impossibly far away. That he underestimated. That figured out I'd be stuck here, perhaps at the same moment I did. Whether it's pity on me or revenge on him, I don't care.

I am and am not. But I'll accept the cheat codes.

Krystal Claxton is a computer technician with unfortunate aspirations involving fiction, words and publishing. She enjoys getting distracted by Dragon Con and The Submission Grinder, and frequently disobeys Heinlein's rules. 